\title{
PENDIDIKAN ISLAM DI INDONESIA SEBELUM PROKLAMASI KEMERDEKAAN
}

Oleh: M. Rusdi

\begin{abstract}
Islamic education is a way to spread the Islamic teachings. Therefore, to establish Islamic educational institutions must be a program for Muslims. For the first time, Islamic education in Indonesia was conducted traditionally. It was conducted between the Islamic traders as teachers and the society who wanted to buy something as students. The traders also conducted al-da'wah bi al-häl (showing good behavior to the society). Therefore, the society was interested in the Islamic traders who brought also the Islamic teaching. Educational method used at that time was sorogan. Students came to the teacher to study. The teachers read and explained their materials to their students and students heard the materials and tried to memorize them. The method then developed to classical system through ma'had or pesantren or boarding schools. The boarding school system keep develop up to the present time, especially in Indonesia.
\end{abstract}

KEYWORDS: Pendidikan Islam, pondok pesantren, madrasah.

PENDIDIKAN sebagai usaha sadar yang dilakukan oleh orang dewasa untuk mendewasakan anak didik diselenggarakan baik melaui jalur sekolah maupun luar sekolah. Hal inilah yang menyebabkan sehingga pendidikan di Indonesia menjadi tanggung jawab bersama antara orangtua, pemerintah, dan masyarakat.

Pendidikan sangat penting dan tidak dapat dipisahkan dengan kehidupan baik dalam kehidupan seseorang dan keluarga, maupun dalam kehidupan berbangsa dan bernegara, karena maju mundurnya suatu bangsa banyak ditentukan oleh maju mundurnya pendidikan bangsa itu.

Sebagai makhluk Tuhan yang menyandang posisi sebagai khalifah di muka bumi, manusia mempunyai empat macam tanggung jawab, yaitu: 1) tanggung jawab terhadap Tuhan sebagai wujud rasa syukur melalui beribadah kepada-Nya, 2) tanggung jawab terhadap diri sendiri yang dimanifestasikan melalui pengembangan kapasitas potensial yang dimiliki agar bermanfaat bagi masyarakat dan lingkungan, 3) tanggung jawab terhadap masyarakat yang diakibatkan munculnya rasa kesatuan, senasib dan 
sepenanggunga dalam mempertahankan diri, dan 4) tanggung jawab terhadap alam semesta yang dimanifestasikan dengan cara menjaga kelestariannya untuk kesejahteraan masyarakat. ${ }^{1}$

Empat macam tanggung jawab itu tentunya harus seimbang dan serasi, sebab bila terjadi stagnasi, maka akan muncul berbagai gejolak. Salah satu upaya untuk dapat menyelaraskan dan menyeimbangkan keempat macam tanggung jawab itu adalah upaya menanamkan kesadaran akan jati diri manusia dan salah satu cara yang dapat ditempuh dalam hal ini adalah melalui pendidikan.

Namun demikian, ada seorang editor, Sindhunata, mengumpulkan sejumlah tulisan ke dalam sebuah buku dan diberi judul yang agak kontroversial. Judul bukunya adalah: Pendidikan Kegelisahan Seumur Hidup. Dalam "Kata Pengantar", ia mengungkapkan: "Sudah menjadi kegelisahan berabad-abad lamanya, bahwa pendidikan dengan amat mudah diperalat untuk melayani kepentingan masyarakat semata-mata. Dalam pendidikan, anak ditempa secara tidak seimbang, sehingga kelak mereka lebih dan makin tersedia sebagai "alat yang berguna" bagi masyarakat. Akan tetapi, sangatlah keliru jika pendidikan memutlakkan kepentingan masyarakat tersebut, sebab tujuan pendidikan bukanlah pertamatama melayani masyarakat tersebut, melainkan membantu kelahiran manusia-manusia dewasa dan matang, yang kelak dengan bebas dan sadar dapat membantu masyarakat.

Lebih lanjut, ia mengatakan, bahwa pendidikan lebih dari sekadar menghasilkan "kegunaan", pendidikan harus membantu manusia muda agar mereka dapat mengolah bakat dan kemampuan persoalnya untuk menemukan kepribadiannya. Pendidikan juga perlu membantu mereka mengembangkan bakat kemampuan sosialnya agar masyarakat juga boleh ikut memetik keuntungan dari perkembangan mereka.

Dalam dunia pendidikan, yang dibutuhkan bukan hanya pengetahuan tentang kenyataan sosial yang ada, melainkan juga kemampuan untuk menilai kenyataan sosial itu berdasarkan kriteria yang ditarik dari suatu sistem nilai. Pembentukan akhlak dalam program pendidikan agama biasanya berupa pelajaran tentang norma-norma atau kaidah-kaidah yang hedaknya ditaati dalam hidup. Nilai-nilai ini biasanya diajarkan dalam bentuk yang abstrak, yang relevansinya terhadap kenyataan sosial tidak mudah ditangkap oleh anak didik, terutama mereka yang belum memiliki banyak pengalaman sosial.

Pendidikan Islam di Indonesia masuk dan berkembang seiring dengan masuk dan berkembangnya agama Islam di Indonesia, karena ajaran Islam dimulai dan disebarluaskan melalui media pendidikan. 
Dengan mengutip ayat pertama dan kedua dalam Q.S. al-'Alaq (96), Mahmud Yunus merinci materi pendidikan Islam itu ke dalam empat macam, yaitu: 1) pendidikan keagamaan, 2) pendidikan aqliyah amaliyah, 3) pendidikan akhlak dan budi pekerti, dan 4) pendidikan jasmani (kesehatan/kebersihan). ${ }^{2}$ Keempat macam materi itu tentunya akan dapat dikembangkan sesuai dengan tuntutan zaman.

Karenanya, untuk melihat sejarah pendidikan Islam di Indonesia tidak akan lepas dari tahapan awal masuknya Islam ke Indonesia yang oleh Buya Hamka disinyalir sudah muncul tidak lama setelah Islam lahir di Mekah. Menurut Hamka, pada tahun 674 M. sudah ada pemukiman orangorang Arab (Islam) di Pantai Barat Sumatera. ${ }^{3}$

Dengan menyimak substansi latarbelakang di atas, maka dapat dirumuskan statement of problem dari tulisan ini, yaitu bagaimana eksistensi pendidikan Islam di Indonesia, khususnya sebelum proklamasi kemerdekaan Republik Indonesia?

\section{PENDIDIKAN ISLAM SEBELUM MEMASUKI ABAD XX}

Bangsa Indonesia yang sebelumnya dikenal dengan sebutan Nusantara pada dasarnya merupakan kelompok masyarakat yang religius. Rasyidi mengungkapkan bahwa masyarakat Nusantara purba mempunyai kepercayaan terhadap Tuhan Yang Maha Esa sebagai kekuatan spiritual yang tertinggi. ${ }^{4}$

Dengan demikian, kedatangan Islam dengan mudah dapat diterima oleh masyarakat pesisir tempat berlabuhnya para pedagang. Pola pendidikan yang dilaksanakan selain melalui media dialog antara pedagang dengan pembeli yang merupakan masyarakat di Nusantara, juga melalui dakwah bi al-hăl yang dipraktekkan oleh pedagang muslim dalam berbagai aspek. Selain pola itu, juga dilakukan pengajaran yang dilakukan di Mesjid dan Surau.

Mahmud Yunus memaparkan bahwa dalam setiap desa/kelompok masyarakat didirikan mesjid atau surau sebagai sarana transformasi pendidikan Islam yang di dalamnya diajarkan cara membaca al-Qur'an dan tatacara ibadah dalam Islam, sebagai pendidikan Islam tingkat permulaan (dasar). ${ }^{5}$ Sistem pendidikan Islam dan sarana yang digunakan di era klasik ini kini mulai digunakan kembali dengan menjamurnya pendirian Taman Pendidikan al-Qur'an (TPA) di seluruh Indonesia.

Sistem pendidikan yang digunakan pada masa itu masih sangat tradisional. Ciri ketradisionalannya menurut Abdullah Fajar adalah belum adanya sistematika yang digunakan baik dari obyek, subyek, maupun materi yang diajarkan. ${ }^{6}$ Dalam perkembangan selanjutnya sudah muncul 
upaya mengklasifikasi tingkat pendidikan kepada dua tingkat, yaitu:

1. Pemula yang baru belajar huruf hijaiyyah sampai dapat membaca;

2. Tingkat lanjutan, ditambah dengan mempelajari materi lainnya, seperti qasidah, barzanji, ilmu tajwid, dan belajar kitab kuning. ${ }^{7}$

Dari pemaparan di atas dapat ditegaskan bahwa tujuan utama pendidikan Islam pada masa ini adalah membina murid agar dapat membaca alQur'an, dapat melakukan ibadah dengan baik, dan mempunyai landasan iman yang mumpuni serta beraklak mulia. Para guru yang mengajar hanya mengharapkan keridaan Allah swt. dan tidak terlalu mengharapkan imbalan materi.

Penggunaan sarana mesjid dan surau untuk tempat pendidikan Islam pada hakikatnya tidak berbeda dengan yang dipraktekkan oleh Rasulullah dalam mendidik para sahabatnya. Sedangkan metode yang digunakan dalam pendidikan Islam adalah sistem sorogan, yakni murid belajar pada seorang guru dengan cara membacakan materi yang diajarkan dan menerangkannya dan murid menyimak dan menghafalnya untuk kemudian guru menguji hafalan dan pemahaman murid. Apabila belum paham, maka guru akan menjelaskan kembali. ${ }^{8}$ Selain itu, juga diterapkan sistem halaqah yakni seorang guru mengajarkan suatu materi (yang umumnya mazhab tertentu) dan dikelilingi oleh murid-muridnya. ${ }^{9}$ Kedua sistem ini sudah muncul sejak abad perkembangan Islam, yang berperan dalam pengembangan sistem ini adalah para sahabat, tabi'in, dan generasi berikutnya.

Kesederhanaan materi yang disajikan, sistem yang digunakan, dan sarana yang dimanfaatkan untuk pendidikan Islam ternyata merupakan metode yang sangat efektif dan efisien dalam mencapai tujuan pendidikan yang juga sangat sederhana. Sebab, dengan belum banyaknya tuntutan berbagai macam materi pelajaran yang disajikan, maka murid dengan mudah dapat menyimak dan memahaminya. Sistem pengajaran yang disajikan juga mempermudah terjadinya dialog, apalagi sarana yang dipergunakan adalah mesjid dan surau, maka murid dapat dengan mempraktekkan tata cara beribadah yang diajarkan langsung di bawah pengawasan gurunya.

Dalam perkembangan selanjutnya, pendidikan Islam di Indonesia mulai menapak ke arah kemajuan dengan munculnya pesantren (alma'had), yang sudah muncul pada paruh pertama abad ke-19 M., sebab pada masa itu telah terjadi kontak antara umat Islam dengan umat Islam dari negara-negara lain terutama Timur Tengah. ${ }^{10}$ Setelah dua abad pertama penjajahan Belanda, mereka tidak lagi diizinkan mengadakan kontak langsung dengan dunia Islam lainnya. ${ }^{11}$ Meskipun sebelumnya 
telah muncul beberapa pemuda Nusantara yang telah menimba ilmu di Mekah, seperti Nuruddin al-Raniriy (w. 1658), dari Aceh, Muhammad Arsyad al-Banjariy (w. 1812 M.) dari Martapura-Banjarmasin. ${ }^{12}$ Meskipun lembaga pesantren ini juga menggunakan sistem sorogan dan halaqah, tetapi lembaga pendidikan ini mempunyai ciri khas tersendiri yang umumnya berada dalam suatu kawasan yang jauh dari kebisingan kota, adanya kiai, santri, pondok dan mesjid, serta memiliki panca jiwa pesantren, yakni: keikhlasan, gotong royong, sosial dan saling menghormati, hidup mandiri, dan kesederhanaan.

Adapun tujuan utama pendidikan di pesantren ialah:

1. Mencetak ulama yang menguasai ilmu-ilmu agama;

2. Mendidik kaum muslimin untuk dapat melaksanakan syariat agama;

3. Mendidik agar anak didik memiliki keterampilan dasar yang relevan dengan terbentuknya masyarakat beragama. ${ }^{13}$

Dengan demikian, dapat digambarkan bahwa tujuan utama pesantren adalah mencetak kader ulama yang mumpuni dalam bidang agama dan mampu mengamalkan serta mengembangkannya dalam masyarakat.

Dengan munculnya pesantren, maka pendidikan Islam telah muncul dalam bentuk kelembagaan dan materi yang diajarkan pun sudah mulai sistematis dengan berpatokan pada berbagai kitab kuning, karenanya pesantren dapat menelorkan banyak tokoh ulama yang kharismatik.

Pondok pesantren sebagai salah satu lembaga pendidikan Islam yang banyak dikenal di Indonesia, telah menyelenggarakan pendidikan untuk mendalami ilmu agama Islam dan mengamalkannya sebagai pedoman hidup keseharian dengan menekankan pentingnya moral dalam hidup bermasyarakat.

Menelusuri sejarah pendidikan di Indonesia, ditemukan bahwa pondok pesantren juga merupakan salah satu bentuk kebudayaan asli bangsa Indonesia yang telah tumbuh dan berkembang di tengah-tengah masyarakat dengan memadukan tiga unsur pendidikan yang sangat penting, yaitu ibadah untuk menanamkan iman, tablig untuk penyebaran ilmu, dan amal untuk mewujudkan kegiatan kemasyarakatan dalam kehidupan sehari-hari. ${ }^{14}$

Diakui oleh banyak kalangan, bahwa pondok pesantren merupakan lembaga pendidikan yang telah ikut serta mencerdaskan kehidupan bangsa dan pada zaman kolonial sangat berjasa bagi umat Islam, karena tidak sedikit pemimpin bangsa, terutama dari angkatan 1945, adalah alumni atau setidak-tidaknya pernah belajar di pondok pesantren. ${ }^{15}$

Keberhasilan yang telah dicapai oleh pondok pesantren dalam menelorkan sejumlah alumni tidak saja berperan dalam bidang politik, tetapi 
juga sukses dalam menghasilkan sejumlah besar ulama yang berkualitas tinggi yang dijiwai oleh semangat untuk menyebarluaskan dan memantapkan keimanan orang-orang Islam. ${ }^{16}$

Peranan yang dilakukan oleh pondok pesantren dalam partisipasinya membangun manusia seutuhnya dan mempertahankan kemerdekaan Indonesia, tidak terlepas dari potensi kultural edukatif yang dimilikinya dalam memobilisasi bangsa, terutama gaya dan tipe kepemimpinan kiai yang lebih menyentuh komunitas besar di Indonesia.

Perkembangan endidikan Islam di era ini tidak dapat dilepaskan dari peranan munculnya kerajaan-kerajaan Islam saat itu, seperti Kerajaan Samudera Pasai (1297), Kerajaan Aceh (1514), Kerajaan Demak (1500), Kerajaan Banten 1527), Kerajaan Ternate dan Tidore (abad ke-16), dan Kerajaan Makassar (abad ke-17). Peran kerajaan Islam ini menurut Hasjimi dibuktikan ketika Iskandar Muda berkuasa (1607-1636) di Aceh banyak didirikan pesantren. ${ }^{17}$ Kondisi demikian terus berlangsung sampai muncul ide-ide pembaruan yang dibawa oleh sebagian alumni Timur Tengah, khususnya bagi mereka yang dapat membaca dan menyimak serta terpengaruh oleh ide Muhammad Abduh dan Rasyid Rida dengan majalah al-Manarnya.

\section{PENDIDIKAN ISLAM MEMASUKI ABAD XX}

Sadar akan perlunya kemerdekaan, bangsa Indonesia bangkit untuk melepaskan diri dari penjajahan Belanda dengan berdirinya Budi Utomo tanggal 20 Mei 1908 yang bertujuan memajukan pendidikan dan kebudayaan serta meningkatkan martabat dan kehidupan rakyat Indonesia, kemudian disusul dengan berdirinya organisasi Islam, seperti Sarikat Islam (1912), Muhammadiyah (1912), dan Nahdatul Ulama (1926). Semua organisasi tersebut berusaha meningkatkan pendidikan Islam, sekalipun diakui antara ketiganya mempunyai berbagai perbedaan, tetapi diakui dari pesantren banyak muncul tokoh-tokoh pejuang kemerdekaan, dengan berdirinya front kemiliteran Hizb Allah (dengan panglimanya K. H. Zainal Arifin) dan Sabil Allah (dengan panglimanya K. H. Masykur). ${ }^{18}$

Hadirnya tokoh-tokoh muda alumni Timur Tengah menggugah mereka untuk mengadakan pembaruan dalam bidang pendidikan dan muncul anggapan bahwa sistem sorogan dan halaqah pesantren perlu diperbarui dengan sistem klasikal, karenanya didirikanlah madrasah.

Madrasah yang mula-mula berdiri menurut Mahmud Yunus adalah Madrasah al-Adabiyyah yang berdiri di Padang yang dipandang sebagai madrasah pertama di Minangkabau, bahkan di Indonesia. ${ }^{19}$

Di samping itu, di Surabaya telah muncul pula ide pembaruan dengan diawali berdirinya kelompok diskusi Taswir al-Afkar yang didirikan 
oleh Abdul Wahab Hasbullah dan Mas Mansur. Dari Taswir al-Afkar ini lahir kelompok kerja Nahdatul Watan dengan program utama bidang pendidikan yang kemudian berhasil mendirikan Madrasah Khizb al-Watan di Surabaya, Madarasah Ahl al-Watan di Wonokromo, Furu' al-Watan di Gresik dan Hidayat al-Watan di Jombang. ${ }^{20}$

Ada perbedaan antara pesantren dan Madrasah. Pesantren dengan sistem sorogan dan halaqah menganut sistem individual, tetapi madrasah memakai sistem klasikal. Di samping itu materi yang diajarkan di madrasah tidak hanya sebatas ilmu agama, tetapi juga ilmu pengetahuan umum.

Pengertian dasar pesantren adalah tempat belajar para santri, sedangkan pondok berarti rumah atau tempat tinggal sederhana yang terbuat dari bambu atau dalam bahasa Arab, "فندوق' berarti hotel atau asrama, sehingga pondok pesantren merupakan lembaga pendidikan yang menampung para santri untuk belajar. ${ }^{21}$

Penamaan umum terhadap lembaga pendidikan Islam tradisional di kalangan umat Islam Indonesia ialah pesantren atau pondok yang terkadang digabungkan menjadi pondok pesantren. Kata pesantren diangkat dari kata santri yang berarti murid atau shastri yang berarti huruf, karena di pesantren inilah mula-mula santri belajar mengenal dan membaca huruf, sedangkan pondok yaitu perumahan sederhana yang dipetak-petak menjadi kamar-kamar sebagai asrama bagi para santri, sehingga istilah pondok pesantren merupakan keseluruhan lingkungan masyarakat tempat para santri mukim dan menuntut ilmu. ${ }^{22}$

Sebagai lembaga pendidikan tradisional Islam di Indonesia, pondok pesantren menekankan pentingnya mempelajari, memahami, mendalami, menghayati, dan mengamalkan ajaran Islam dengan lebih menekankan moral keagamaan sebagai pedoman perilaku sehari-hari. ${ }^{23}$

Sesuai dengan pengertian dasar tersebut, maka pondok pesantren merupakan lembaga pendidikan Islam yang memiliki sejumlah unsur pokok yang membedakan dengan lembaga pendidikan lainnya, yaitu: pondok, mesjid, santri, kiai, serta pengajaran kitab-kitab Islam klasik. Pondok sebagai unsur pokok sebuah pondok pesantren pada dasarnya adalah asrama pendidikan Islam di mana para santri tinggal bersama dan belajar di bawah bimbingan guru yang lebih dikenal dengan sebutan kiai. ${ }^{24}$

Pondok yang semula dimaksudkan sebagai tempat tinggal atau asrama para santri untuk mengikuti dengan baik pelajaran yang diberikan oleh kiai sekaligus sebagai tempat latihan bagi santri untuk bekerja memenuhi kebutuhan hidup sehari-hari dalam suasana kekeluargaan dan bergotong royong di bawah bimbingan kiai agar mampu hidup mandiri dalam masyarakat, kini telah berkembang menjadi tempat pemondokan atau 
asrama yang pemeliharaannya diperoleh dari sewa atau iuran setiap santri. ${ }^{25}$

Lembaga pendidikan pesantren dan madrasah terus berkembang dan bermunculan di berbagai daerah dengan aneka bentuk, jenjang pendidikan dan kurikulum masing-masing yang tidak seragam. Untuk menyeragamkan pelaksanaan pendidikan madrasah ini, maka pada tanggal 2-5 Juni 1936 diadakan Muktamar di Padang Panjang. ${ }^{26}$

Dari muktamar itu dihasilkan kesepakatan bahwa tingkatan pendidikan madrasah haruslah dengan berjenjang: Awwaliyyah, Ibtidaiyyah, Tsanawiyyah, Mu'allimin, dan al-Jami'ah al-Islamiyyah, juga memasukkan pendidikan umum dalam setiap jenjang pendidikan.

Sementara itu penjajah Belanda mengamati munculnya gerakan untuk melepaskan diri dari penjajahan. Oleh karena itu, Belanda berusaha untuk memecah belah masyarakat yang pada realitasnya telah terjadi pertentangan, yakni antara kelompok sinkretis (tradisional) dengan Wahabi, antara Kerajaan Hindu Budha dengan Kesultanan Islam, bahkan lembaga pesantren yang tidak mau menerima subsidi Belanda disingkirkan ke daerah pedalaman, sehingga membuat pesantren tertutup dari kema-juan modern. ${ }^{27}$ Usaha yang demikian itu dilakukan oleh Belanda untuk membendung munculnya perjuangan masyarakat dan kaum santri untuk bersatu dan merdeka.

Keterasingan akibat tekanan Belanda yang dialami pesantren berbalik ketika Jepang datang ke Indonesia pada tahun 1942. Meski Jepang masih menerapkan sistem adu domba, tetapi lebih memilih kalangan ulama untuk mengganti kedudukan priyayi, sehingga sejak itu pesantren mendapatkan nafas baru untuk tinggal landas dan membenahi diri dari ketertinggalan. ${ }^{28}$

Dengan demikian, maka sejarah mencatat, betapa heroik dan patriotnya kalangan santri di bawah komando kiainya dengan basis pesantren dalam usaha melepaskan diri dari penjajahan yang dimulai dari pembenahan sistem pendidikan.

\section{PENUTUP}

Pendidikan merupakan salah satu sarana untuk menyebarkan ajaran Islam, karenanya mendirikan lembaga pendidikan meski dalam bentuk yang sederhana merupakan sesuatu yang tak terelakkan.

Agama Islam masuk ke Indonesia yang secara fitrah merupakan mawsy religius dapat dengan mudah beradaptasi. Untuk menyebarkan agama Islam perlu adanya pendidikan. Oleh karena itu, awal munculnya pendidikan Islam di Indonesia bersifat sangat sederhana yang kemudian 
secara lambat laun menemukan suatu pola yang dibentuk sesuai dengan perkembangan zaman. Hal ini mengindikasikan bahwa pendidikan Islam itu adalah suatu keharusan dengan sistem yang fleksibel yang dapat dikembangkan sesuai situasi dan kondisi. Dari dari itu, yang terpenting adalah tercapainya tujuan utama pendidikan Islam itu sendiri.

\section{CATATAN AKHIR}

1. Yusuf Amir Feisal, Reorientasi Pendidikan Islam, cet. I, Jakarta: Gema Insani Press, 1995, h. 63-65.

2. Mahmud Yunus, Sejarah Pendidikan Islam, cet. VII, Jakarta: Hidakarya Agung, 1992, 5-6.

3. Hamka, Sejarah Umat Islam, Jakarta: Nusantara, 1961, h. 660-662. Lihat juga Ibrahim Bukhari, Pengaruh Timbal Balik antara Pendidikan Islam dan Pergerakan Nasional di Minangkabau, Jakarta: Gunung Tiga, 1981, h. 33.

4. M. Rasyidi, Strategi Kebudayaan Pembaharuan Pendidikan Nasional, Jakarta: Bulan Bintang, 1980, h. 72.

5. Mahmud Yunus, Sejarah Pendidikan Islam, h. 34.

6. Abdullah Fajar, Peradaban dan Pendidikan Islam, Jakarta: Rajawali Press, 1991, h. 66.

7. Mahmud Yunus, Sejarah Pendidikan Islam, h. 35

8. Jamal D. Rahman et al., Wacana Baru Figh Sosial, cet. I, Bandung: Mizan, 1997, h. 6-7.

9. Hasbullah, Pendidikan Islam di Indonesia, Jakarta: PT. Raja Grafindo Persada, 1995, h. 23.

10. Muhammad 'Athiyyah Abrasyiy, al-Tarbiyyah wa Falsafatuh, Mesir: Isa al-Babiy al-Halabiy, 1975, h. 71.

11. Slamet Efendi Yusuf, et. al., Dinamika Kaum Santri, Jakarta: Rajawali, 1983, h. 4.

12. Azyumardi Azra, Jaringan Ulama, cet. I, Bandung: Mizan, 1995, h. 166 dan 252.

13. Yusuf Amir Feisal, Reorientasi Pendidikan Islam, h. 183-184.

14. A. Timur Djaelani, Peningkatan Mutu Pendidikan dan Pembangunan Perguruan Agama, Jakarta: Dermaga, 1980, h. 52.

15. Mastuhu, Dinamika Sistem Pendidikan Pesantren, Jakarta: INIS, 1994, h. 3.

16. Zamakhsyari Dhofier, Tradisi Pesantren. Jakarta: LP3ES, 1982, h. 20.

17. A. Hasjimi, Sejarah Kebudayaan Islam di Indonesia, Jakarta: Bulan Bintang, 1990, h. 192.

18. Slamet Efendi Yusuf, et. al., Dinamika Kaum Santri, h. 37.

19. Mahmud Yunus, Sejarah Pendidikan Islam, h. 63.

20. Slamet Efendi Yusuf, et. al., Dinamika Kaum Santri, h. 7.

21. Departemen Agama R.I., Sejarah Pendidikan Islam di Indonesia, Jakarta: Proyek Pembinaan Prasarana dan Sarana Perguruan Tinggi Agama/IAIN di Jakarta, 1986, h. 53.

22. A. Timur Djaelani, Peningkatan Mutu Pendidikan dan Pembangunan Perguruan Agama, h. 53. 
23. Mastuhu, Dinamika Sistem Pendidikan Pesantren, h. 55.

24. Zamakhsyari Dhofier, Tradisi Pesantren, h. 44

25. Departemen Agama R.I., Sejarah Pendidikan Islam di Indonesia, h. 57.

26. Mahmud Yunus, Sejarah Pendidikan Islam, h. 109.

27. Yusuf Amir Feisal, Reorientasi Pendidikan Islam, h. 196.

28. Yusuf Amir Feisal, Reorientasi Pendidikan Islam, h. 197.

\section{DAFTAR PUSTAKA}

Abrasyiy, Muhammad 'Athiyyah, al-Tarbiyyah wa Falsafatuh, Mesir: Isa al-Babiy alHalabiy, 1975.

Azra, Azyumardi, Jaringan Ulama, cet. I, Bandung: Mizan, 1995.

Bukhari, Ibrahim, Pengaruh Timbal Balik antara Pendidikan Islam dan Pergerakan Nasional di Minangkabau, Jakarta: Gunung Tiga, 1981.

Departemen Agama R.I., Sejarah Pendidikan Islam di Indonesia, Jakarta: Proyek Pembinaan Prasarana dan Sarana Perguruan Tinggi Agama/IAIN di Jakarta, 1986.

Dhofier, Zamakhsyari, Tradisi Pesantren. Jakarta: LP3ES, 1982.

Djaelani, A. Timur, Peningkatan Mutu Pendidikan dan Pembangunan Perguruan Agama, Jakarta: Dermaga, 1980.

Fajar, Abdullah, Peradaban dan Pendidikan Islam, Jakarta: Rajawali Press, 1991.

Feisal, Yusuf Amir, Reorientasi Pendidikan Islam, cet. I, Jakarta: Gema Insani Press, 1995.

Hamka, Sejarah Umat Islam, Jakarta: Nusantara, 1961.

Hasbullah, Pendidikan Islam di Indonesia, Jakarta: PT. Raja Grafindo Persada, 1995.

Hasjimi, A., Sejarah Kebudayaan Islam di Indonesia, Jakarta: Bulan Bintang, 1990.

Mastuhu, Dinamika Sistem Pendidikan Pesantren, Jakarta: INIS, 1994.

Rahman, Jamal D. et. al., Wacana Baru Figh Sosial, cet. I, Bandung: Mizan, 1997.

Rasyidi, M., Strategi Kebudayaan Pembaharuan Pendidikan Nasional, Jakarta: Bulan Bintang, 1980.

Yunus, Mahmud, Sejarah Pendidikan Islam, cet. VII, Jakarta: Hidakarya Agung, 1992.

Yusuf, Slamet Efendi et. al., Dinamika Kaum Santri, Jakarta: Rajawali, 1983. 